где студенты практикуют базовые навыки преподавания перед своими однокурсниками. Вторая - основная практика преподавания - происходит в основном в специальных экспериментальных школах, которые управляются университетами и имеют аналогичные учебные планы, как и в обычных государственных школах. Будущие учителя начальных школ проводят около 15 процентов времени обучения (около 40 кредитов ECTS) на практике в школах. Для студентов - предметников это время составляет примерно одну треть учебного плана.

Правительство в лице Министерства образования всячески поощряют дальнейшее профессиональное совершенствование педагогов. Финские учителя со степенью магистра имеют право обучаться в докторантуре. Многие преподаватели пользуются возможностью освоить курс докторантуры в области образования, часто одновременно с преподаванием в школе.

Несмотря на то, что финское педагогическое образование было высоко оценено за его систематическую академическую структуру и высокое качество, правительство планирует существенное увеличение бюджетов профессионального развития и рассматривает пути обеспечения того, чтобы все учителя имели доступ к адекватной профессиональной подготовке, постдипломному образованию и курсам повышения квалификации, финансируемыми муниципалитетами. Государственный бюджет ежегодно выделяет около 30 миллионов долларов на профессиональное развитие учителей и директоров школ посредством различных форм повышения квалификации и непрерывного образования. Правительство определяет направленность обучения, основанное на текущих национальных потребностях в области развития образования, и обучение на контрактной основе предоставляется поставщикам услуг на конкурсной основе. Министерство образования совместно с Министерством финансов Финляндии в сотрудничестве с муниципалитетами планировало удвоить государственное финансирование профессионального развития учителей к 2020 году [7].

$$
* * *
$$

1. Helsingin Sanomat, 2004 Helsingin Sanomat (2004). Ykkössuosikki: Opettajan ammatti [Top favorite: Teaching profession]. February 11, 2004.

2. Jakku-Sihvonen \& Niemi, 2006 Jakku-Sihvonen, R. \& Niemi, H. (Eds.) (2006). Researchbased teacher education in Finland: Reflections by Finnish teacher educators. Research Report 25. Turku: Finnish Educational Research Association.

3. OECD (2008). Education at a glance. Education indicators. Paris: OECD

4. Westbury et al., 2005 Westbury, I., Hansen, S-E., Kansanen, P. \& Björkvist, O. (2005). Teacher education for research-based practice in expanded roles: Finland's experience. Scandinavian Journal of Educational Research, 49(5), 475-485.

5. Ministry of Education and Culture. [Электронный pecypc]. - Режим доступа: https://minedu.fi/koulutusselonteko/henkilosto

6. Rodgers C. Defining reflection: Another look at John Dewey and reflective thinking. Teachers College Record. 2002;104(4):842-856

7. Ministry of Finance. Europe 2020 Strategy - Finland's National Reform Programme; Spring 2017. Ministry of Finance publications - 18c/2017

\title{
Шаповалов М.В. \\ Информационно-коммуникационные технологии в системе воспитательной работы учреждений общего образования
}

РГБУ ДПО «Карачаево-Черкесский республиканский институт повышения квалификации работников образования»

(Россия, Черкесск)

doi 10.18411/gq-15-10-2021-08

\section{Аннотация}

Интенсивное развитие процессов информатизации образования определяет возможности совершенствования воспитательной работы учреждений общего образования средствами ИКТ. В статье рассматриваются вопросы организации 
педагогической деятельности учителей в информационном формате урока. Предлагаются решения проблемы интеграции интеллектуального и физического труда, проблемы усиления воспитывающего потенциала аксиологического подхода к осуществлению образовательного процесса школы.

Ключевые слова: Информационно-коммуникационные технологии, воспитательная работа, развитие личности, интеграция интеллектуального и физического труда, урок, образование, учреждение общего образования.

\section{Abstract}

The intensive development of the processes of informatization of education determines the possibilities of improving the educational work of general education institutions by means of ICT. The article deals with the organization of pedagogical activity of teachers in the information flow of the lesson. The solutions to the problem of integration of intellectual and physical labor, the problem of strengthening the educational potential of the axiological approach to the implementation of the educational process of the school are proposed.

Keywords: Information and communication technologies, educational work, personal development, integration of intellectual and physical labor, lesson, education, general education institution.

Инновационные концепции преподавания школьных предметов, включенных в действующие Федеральные образовательные стандарты общего образования (начального общего образования - НОО, основного общего образования - ООО), ориентированы на создание условий для совершенствования методики их изучения. В эпоху цифровизации непрерывного образования совершенствование методик изучения школьных дисциплин предполагает обязательность разработки системы заданий по эффективному использованию информационно-коммуникационных технологий, оптимизирующих процессы достижения школьниками планируемых результатов учебной деятельности.

Анализ личностных достижений обучающихся, осуществляемый в контексте оценки качества и мониторинга результатов освоения программы ,позволяет согласиться с выводами о необходимости усилить внимание к изучению предметов, интегрирующих возможности гармоничного развития умственной и трудовой деятельности [7]. Таким предметом в условиях обучения школьников 1-4 классов, 5-9 классов является технология, теоретическое и практическое содержание которого связано с уникальным феноменом труд,а его функциональная природа формировалась и развивалась в условиях исторического процесса человека разумного. Классический путь динамических изменений этого явления - труд отражал сначала приоритет физического, затем - интеграцию физического и умственного (смешанный труд), впоследствии - приоритет умственного.

Уникальность нашего времени, по мнению ученых Э.Ф. Зеер, А.И. Кочетова, С.Н.Чистяковой, А.Д. Шатовой, М.П. Щетинина и др., во многом определяется реалиями происходящего антропологического кризиса, рисками недооценивания позитивного влияния труда, трудовой деятельности, трудового воспитания, физической нагрузки на развитие ребенка, взрослеющего человека.

В логике антропологического кризиса очевидна опасность негативной тенденции утраты традиционного отношения к труду как мощному, единственному потенциалу финансово-экономической устойчивости человека, его социального, финансового, духовно-нравственного благополучия. При этом, пишут М.К. Мамардашвили, А.Г. Асмолов, В.И. Слободчиков, В.И.Букреев и др., усиливаются деструктивные явления «расчеловечивания человека». Вопрос: что делать? объединяет ученых и практиков, признающих необходимость разработки методик психолого-педагогической поддержки укрепления мотивационного отношения детей к 
признанию труда не только как ценностно необходимой черты характера личности, но и как социально-ценностного качества человека, противостоящего опасности лени разрушительного порока человека. Базовые основания такой направленности в изучении школьных предметов прозрачно сформулированы в Законе об образовании в РФ, признающем приоритетность воспитания при трактовке феномена образование: «образование - единый целенаправленный процесс воспитания и обучения». (статья 2). Целью образования сегодня признано интеллектуальное, духовно-нравственное, творческое, физическое и (или) профессиональное развитие человека. Деятельностью, обеспечивающей такое многоплановое развитие личности (интеллектуальное, духовное, физическое, трудовое и т.д) становится воспитание. Следовательно, целостность образовательного пространства Российского государства (самого большого в мире по территории ) стратегически поддерживается ориентиром на процессуальность образования и деятельностную обеспеченность ресурсами интеллектуального, физического, духовно-нравственного воспитания. Итак, признание целевого предназначения трудового воспитания, наряду с воспитанием духовно-нравственным, очевидно. Это, с нашей точки зрения, укрепляет педагогические основания преподавания школьных дисциплин,процесс формирования средствами этих дисциплин условий для позитивной мотивации отношения обучающихся к труду, трудовой деятельности , но только не в ущерб овладения ими информационной грамотностью и информационной культурой. Анализ учебной деятельности школьников, как показывают данные нашего педагогического эксперимента (2016-2020), подтверждает выводы о том, что в детской среде значительно повышается интерес к использованию ИКТ, ориентированных на трудовую деятельность, связанную с конструированием и моделированием вещей, изготовление которых в материале производят сами обучающиеся.(7) В процессе интеграции трудовых процессов (интеллектуальных, физических) школьники испытывают радость творческих открытий, удовлетворение результатами своего труда (материализация замысла в своем авторском рукотворном изделии). В таких условиях вызревают реальные возможности для преодоления тенденциозного игнорирования физического труда, преодоления психологического барьера отрыва труда физического от интеллектуального.

В систему условий, важных для использования дидактических ресурсов ИКТ в работе по трудовому воспитанию, по совершенствованию методики преподавания школьных предметов, включается деятельность по формированию у обучающихся «практических умений и опыта, необходимого для организации собственной жизни» [2, c.2].

Знакомство с опытом использования ИКТ в работе по трудовому воспитанию в регионах РФ открывает особые достижения учреждений образования, например, Республики Татарстан(4;6).Адаптированный к условиям жизни других регионов,этот опыт значительно обогащает методики проведения уроков технологии в информационном формате. Так, разрабатываются задания на применение компьютерной графики при проектировании моделей с последующим их воплощением «в материале», что соответствует возможностям интеграции интеллектуального и физического труда, необходимым для освоения умений и навыков в сфере робототехники, конструирования в информационном потоке при оптимальном введении в урок процессов ручного труда. Практика показывает, что при этом открываются новые возможности профессиональной ориентации, поддерживающей престиж рабочих профессий, интерпретирующей изменения в системе среднего профессионального образования: подготовка специалистов по программе «Профессионалитет», на обучение по которой уже в 2022 году будет принято около 150000 человек для обучения в колледжах. 
Повышение плотности и эффективности информационного потока на уроках технологии предполагает освоение школьниками ключевых понятий, отражающих содержание этой дисциплины. При этом широко используются ресурсы интернета для актуализации средств национального корпуса русского языка, способов толкования лексического значения опорной лексики и фразеологии уроков технологии, для интерпретации синонимических рядов, включающих эти номинативные единицы. В экспериментальной работе в состав ключевых понятий уроков технологии включались такие языковые единицы, как: труд, безопасность жизнедеятельности, охрана здоровья, учебная деятельность, физический труд, умственный труд, конструирование, моделирование, профессиональная ориентация, информационная безопасность, виды трудовой деятельности, творческа деятельность, исследовательская деятельность, профессиональная подготовка, ручной труд, рынок труда, рукотворный мир, нерукотворный мир и т.д.

Деятельностно-системный, аксиологический подходы к организации применения интернета на уроках технологии создают условия для соединения физического и интелектуального труда, значительно снижают риски «непонимания детьми реальности» ( М.К. Мамардашвили), укрепляют образовательную среду школы продуктивной деятельностью по трудовому воспитанию обучающихся средствами информационно-коммуникационных технологий.

$$
* * *
$$

1. Аствацатуров Г.И. Технологии конструирования мультимедийного урока. - М., 2002. -26 c.

2. Глоба-Михайленко И.Д. Модель организации трудового воспитания в муниципальном бюджетном учреждении дополнительного образования «Эколого-биологический центр имени С.Ю. Соколова» г. Сочи. - Сочи: 2017. - 12 с.

3. Гузеев В.В. Образовательная технология XXI века: деятельность, ценности, успех. - М: Центр «Педагогический поиск», $2009-230$ с.

4. Инновационные педагогические технологии : Материалы II Международной научной конференции. - Казань: Бук, 2015. - 78 с.

5. Мамардашвили М.К. Философские чтения,.СПб: Азбука-классика, 2002.-822c.

6. Новые информационные технологии в образовании // Материалы международной научнопрактической конференции. - Екатеринбург: РГППУ, 2012. - 538 с.

7. Шаповалов М.В. Образовательный мониторинг в управлении качеством подготовки специалисто в учреждениях среднего профессионального образования. - Ставрополь : СКИПКРО, 2005. - 72 с.

8. Яковлев С.В. Воспитание ценностных оснований личности. - М.: Инфра , 2017. 147c. 